\title{
Rethinking employability: how students build on interest in a subject to plan a career
}

\author{
Kathleen M. Quinlan ${ }^{1}$ (D) K. Ann Renninger ${ }^{2}$ (D)
}

Accepted: 6 December 2021 / Published online: 7 January 2022

(c) The Author(s), under exclusive licence to Springer Nature B.V. 2021

\begin{abstract}
As universities prioritise employability, there is increased attention to promoting students' career decidedness. In this mixed method, cross-sectional study, we explore whether and how students' interest in their academic subject affects their career decidedness. Using surveys of 428 undergraduates studying sciences in a UK university $(60 \% \mathrm{~F}$, average age $=19.9)$ and case examples from follow-up interviews with 15 students, we examine students' interest development and its relation to their career decidedness and their desire for meaningful, interesting work. Findings showed that most students who were studying science in university had a well-developed interest that had motivated their choice of programme, and their subject interest and career decidedness were linked. Regression analyses indicated that students' interest in their subject was a significant predictor of career decidedness, mediated by students' desire to pursue that interest in their career. Openended comments on the surveys suggested that decidedness was informed by coursework, proactive career exploration, work experience, interest, feasibility, and familial contacts. Interviews confirmed these factors and illustrated how they contributed to students' career decidedness. We propose implications for academics and career counsellors who might help students refine their interest by considering connections between their academic subject, interest, and related career options. We argue that educators and policy-makers need to reframe employability interventions and think beyond teaching students skills or attributes that lead to employment. Educators can start with students' interest in their subject and support students' exploration of how they can continue to pursue that interest in various careers.
\end{abstract}

Keywords Employability $\cdot$ Subject interest $\cdot$ Science interest $\cdot$ Higher education $\cdot$ Careers education $\cdot$ Career values

Kathleen M. Quinlan

K.M.Quinlan@kent.ac.uk

1 Centre for the Study of Higher Education, University of Kent, UELT Building,

Canterbury CT2 7NZ, UK

2 Department of Educational Studies, Swarthmore College, Swarthmore, PA, USA 


\section{Introduction}

Employability following higher education (HE) is a priority for students, as well as their universities. Having clear career plans is associated with graduates' positive career outcomes, so it is important for higher education (HE) institutions to find ways to support students' career decidedness and decision-making (Shury et al. 2017).

Consider Lucy's case:

Lucy, a final year university student, has enjoyed science since she was a child, relishing science shows on television and pouring over her mother's book of 101 Childhood Ailments. She chose biology at A-Levels and Bioscience for her BSc to pursue that interest, though she had no particular career plan in mind. She knows she doesn't want to be a doctor and that she wants something that will be enjoyable over the long term. She is concerned that many of her science friends who graduated six months ago do not have "real" jobs yet.

Lucy's story highlights the challenge that students face during HE: to identify and clarify their interest in a particular subject and make use of it to inform their decisionmaking about a specific career plan. Because students, like Lucy, tend to choose their degree based on interest in the subject (Vulperhorst et al. 2020; Mikkonen et al., 2009) and enter HE undecided about their careers (Cobb \& Winter, 2018), the subsequent role of students' subject interest in their career planning and decidedness needs further study.

In contrast to the tendency of careers researchers to focus on vocational or occupational interests as developed traits or personality characteristics that can be matched to careers on completion of a degree (e.g. Su, 2018), our consideration of interest is developmental (Hidi \& Renninger, 2006). Interest refers to both a psychological state of individuals during engagement and the predisposition to re-engage particular content meaningfully over time. Whereas motivation or engagement can be instrumental and not necessarily meaningful, interest is always associated with meaning making and deeper understanding (Renninger \& Hidi, 2016). This framing of interest enables us to examine connections students make between their subject of study and their later career decision-making. As such, it also suggests an original and significant reframing of the HE employability agenda to focus on developing students' interests.

\section{Interest and career values}

Recent research suggests that students' career choices may be based more on 'interest, the learning possibilities and the feeling that the career is in accordance to the self' (Sortheix et al., 2013, 468), rather than on instrumental, extrinsic aims such as salary, rewards, and status (AGCAS, 2017; Gallup, 2019; Jackson \& Bridgstock 2018; Jackson \& Tomlinson, 2019; Sortheix et al., 2013).

Studies in the USA have found that recent graduates are likely to be focused on values such as pursuing meaningful and interesting work (Gallup, 2017, 2019). A recent survey of 2,205 US HE graduates showed that $80 \%$ sought meaning and purpose in their work, although less than half of them experienced it (Gallup, 2019). In fact, only 34\% reported that they were 'deeply interested in the work they do', and only $26 \%$ agreed that they 'do something interesting every day'. This kind of disengagement among workers 
is concerning because it is associated with low levels of well-being and organisational productivity (Harter et al. 2016).

Gallup (2019) reported that graduates who experienced a sense of purpose in their work were more likely to (a) align their work with their interests, values, and strengths; (b) be reflective about those qualities in themselves; (c) have had an internship; (d) be encouraged to pursue their goals while also being given realistic expectations related to employment; and (e) participate in a programme or class that helped them think about pursuing meaningful work. They concluded that the challenge is for HE institutions to prepare students not just for employability, but for meaningful work that engages their interests, values, and strengths. Because it is centred on skills, the current employability agenda in the UK and Australian HE does not yet do so (Holmes, 2013; Yorke, 2006). Our study responds to this call by focusing on students' interest development and its potential connections to career decidedness.

In the UK, 58\% of a sample of 1300 first year students from four different universities said that doing something they really enjoy was the most important factor in their future careers, alongside leading other people (73\%), and a chance to progress (65\%) (AGCAS, 2017). Similarly, Shury and colleagues (Shury et al. 2017) found that two and a half years after completing their bachelor's degree, graduates who were dissatisfied with their work cited lack of connection with their degree subject and their own interest.

Greater awareness of the importance of students' employment-related values has prompted recent policy change in the UK. In 2018, the government replaced the Destination of Leavers of Higher Education (DLHE) with the Graduate Outcomes survey (GO). The DLHE was typical of tools used in various developed countries for measuring graduate employment outcomes. These tools have been criticised for over-emphasis on extrinsic values such as salary and insufficient attention to intrinsic values such as graduates' satisfaction and motivation (Jackson \& Bridgstock, 2018). Like the DLHE, GO gathers information about graduates' career destinations, though it does so at 15 months after graduation instead of 6 months. In addition, the GO measures graduates' reflections on the meaningfulness of their work, whether they are using what they learned in their degree course, and whether it fits with their future plans (https://www.hesa.ac.uk/innovation/outco mes). To ensure graduate satisfaction with their careers, HE educators need to understand how students think about the connection between degree subject, their interests, and their careers. Although others have considered how students approach their employability (e.g. Tomlinson, 2007), the role of subject interest in employability development has not been explored. We address this gap in the literature. Helping students to identify, reflect on, and develop their interest may be an important foundation for their career planning (Akkermans et al., 2013).

\section{Vocational interest}

Although there has been a recent focus on students' interest in the career values literature, interest is not a new concept in vocational psychology. There is a long and venerable tradition of using vocational interest scales to match individuals to careers (e.g. Holland, 1959; Lent et al. 1996; see Su, 2018 for a review). To understand and support students' development during HE, though, this practice has several shortcomings. First, this type of vocational interest information focuses on individuals' traits and their match to particular careers, rather than seeing interest as something that can grow and develop with appropriate support ( $\mathrm{Su}, 2018)$. Second, the categories of interest in those scales may not be clearly 
aligned to particular degree subjects on which students like Lucy are focussed. Third, these kinds of assessments are often conducted towards the end of a students' degree.

The current framing of career values (e.g. Sortheix et al., 2013) outlined above demands a different, more developmental-educational approach to interest. In particular, students starting HE need to be supported to optimise their time during university and seize opportunities that could increase their chances of attaining a meaningful, interesting job on graduation. Such guidance requires understanding how interest develops during HE. It also requires better understanding the subject interests students bring with them to $\mathrm{HE}$ and their connection to clear career plans (decidedness).

\section{Conceptual framework: interest development}

To explore the link between subject interest and career decidedness for university students like Lucy, we draw on the four-phase model of interest development (Hidi \& Renninger, 2006). Although interest as a variable was recognised by early educators (e.g. Dewey, 1913), they did not conceptualise it as developmental. The Hidi and Renninger model is unique. It considers change over time and is as applicable to the experience of HE students as it is to younger children. Interest is a meaningful engagement with a subject, together with a desire to re-engage with that subject. The model is a sociocultural model in that interest develops through interactions with other people and opportunities in the environment such as coursework or internships. It is also a model that is grounded in physiology. Neuroscientific evidence has demonstrated that all individuals are hardwired to develop interest, and the reward circuitry in the brain is activated when individuals engage in repeated information search (e.g. Gottlieb et al., 2013). ${ }^{1}$

The development of interest begins with the initial triggering of interest in some content (e.g. biology), which, if sustained, continues to develop through phases which have been shown to be distinct from and yet coordinated with other motivational variables such as goals (e.g. Harackiewicz, et al., 2008), self-efficacy (e.g. Nuutila, et al., 2020), and self-regulation (e.g. Sansone et al., 2019). Learners who have little to no interest are not likely to be positioned to set goals, feel self-efficacious, or self-regulate how they engage with content without support from other people or the design of the environment to make meaningful connections to content. By contrast, learners with more developed interest are able to set goals, feel self-efficacious, and self-regulate - they seek out challenge and feedback-and are able to self-generate meaningful connections, which makes ongoing information search rewarding.

With appropriate conceptual, structural, material, and social support to make their own meaningful connections to the content, individuals develop their own 'lines of practice' through a discipline or field (Azevedo, 2011, 2015). These ways of engaging have the potential to lead students to engage in career exploration and the selection or crafting of

\footnotetext{
1 We note that when conceptualised as a cognitive and affective variable that develops, interest is distinct from and has a relation not only to vocational and occupational interest, but to other motivational constructs. For example, in situated expectancy-value theory (e.g. Eccles and Wigfield, 2020), task interest is used along with importance and utility to assess a person's expectations about possibilities. A developmental approach to interest also differs from, but has a relation to self-determination theory (e.g. Ryan \& Deci, 2020). As a variable that develops, interest is understood to both promote and also be an outcome of psychological needs such as autonomy, competence, and social relatedness (Hidi \& Renninger, 2006).
} 
particular careers that allow them to nurture their interest(s). Interest has been repeatedly shown to benefit academic performance (e.g. Jansen et al., 2016), although the two variables are distinct. Key is whether learners are ready to recognise and make use of opportunities, or need support to do so. There is substantial evidence that learners in earlier and later phases of interest development may benefit from different types of support to engage and that both interest development and academic performance are benefitted (e.g. Hecht et al., 2021). High academic performance in HE and clear career plans (i.e. decidedness) are associated with obtaining a desirable job (Shury et al., 2017). Yet unexamined is the relation between interest in one's chosen subject and its role in career decidedness, which is critical for going beyond the current skill-focused employability agenda. This gap is the focus of the current study.

\section{Research questions and hypotheses}

To understand the factors that influence HE students' career decidedness during HE, we focus on students in science programmes and address two questions:

1) Does HE students' interest in their academic subject predict their career decidedness?

We hypothesise that interest in the subject supports career decidedness (Hypothesis 1). We expect that students who are more interested in their subject will also want to continue to pursue that interest during their careers (Hypothesis 2) and, finally, that this desire to continue to pursue their interest during their careers will mediate between interest in the subject and career decidedness (Hypothesis 3).

To better understand the relation between interest and decidedness from students' perspectives, we also asked:

2) What do students think contributes to their career decidedness?

\section{Methods}

We employed a mixed-methods, cross-sectional design. A survey consisting of open-ended and Likert scale items was distributed to HE science students. In-depth semi-structured interviews were conducted with a subsample of the surveyed students who volunteered to participate. Procedures were approved by the ethics board of the first author's department. Pseudonyms are used in reporting student interview responses, and we have anonymised the institution. First, we briefly describe the study context and then we describe the participants, the survey procedure and measures, and the interview procedure.

\section{Study context}

In the UK, where this study is set, young people make decisions about their courses before entering general secondary school (GCSE, years 10-11, ages 14-16). Guides offer information and advice about choices (e.g. British Broadcasting Corporation, 2021). Pupils again choose courses for upper secondary school (years 12-13, ages 16-18; A levels are the traditional academic route; BTEC courses are more vocationally oriented) (UCAS, 
2021a). Students apply directly to a degree course (programme or major area of study) within a university, which has its own specific educational prerequisites.

'UK degree courses tend to be very specialised from day one, allowing students to focus on their chosen subject' (UCAS, 2021b). In the programmes studied here, students take a set of prescribed courses and only choose different specialties in their final year.

\section{Participants}

First through fourth year undergraduate students $(N=428 ; 60.3 \%$ female; average age $=19.92, S D=1.93)$ in one UK university who were enrolled in either the biosciences degree programme $(n=311)$ or the forensic science degree programme $(n=117)$ completed the survey. Both participating programmes are accredited with relevant professional bodies, which ensure similarity with other accredited programmes. The university is midranked on UK league tables, with entry standards that are also average for the sector. Thus, the sample is typical of students studying these degrees in the UK. With the endorsement of the programme leader and lecturer, students were given 5-10 minutes during a core lecture to complete the survey on paper. The first author briefly described the project to participants as investigating how different curricular and teaching practices affect students' academic and career interest development. Response rates for each class were over $80 \%$. Students were asked on the survey if they would be willing to be interviewed. For the interviews, we opted to focus on third and then second year students, as they would have more experience on which to reflect. We also sought demographic diversity among the interviewees and proportionate representation between the two programmes. In the end, a total of fifteen students were interviewed ( 1 first year, 6 second year, 7 third year, 1 fourth year; 11 biosciences, 4 forensics; 11 female, 4 male).

\section{Survey procedure and measures}

The survey consisted of three open-ended questions addressing the students' choice of subject, their post-university plans, and the factors that contributed to clarifying their post-university plans. Eleven Likert scale items assessed interest based on Quinlan (2019). Three Likert scale items measured students' desire to pursue their subject interest during their career, and three measured career decidedness. Six demographic characteristics were also collected. Each measure is described below. Acronyms used in reporting data in the tables appear in parentheses.

\section{Subject choice}

Students responded to the open-ended question, 'Why did you choose this subject for your BSc degree?' Answers were coded into three dummy variables for referencing careers (e.g. 'Because I wanted to pursue a career in healthcare'), an interest in the subject (e.g. 'I enjoyed biology and chemistry'), or a competency related to the subject (e.g. 'I was good at it.'). 


\section{Interest}

Students rated 11 interest items on a 5-point Likert scale $(1=$ strongly disagree to $5=$ strongly agree) in relation to the overall field of their degree course (i.e. subject interest). The overall scale (Quinlan, 2019) was operationalised based on indicators of interest (Renninger \& Hidi, 2016) and had very good reliability $(\alpha=0.839)$. Quinlan's scale consisted of five items addressing students' independent and voluntary engagement (e.g. 'I talk about this field beyond what is required for classes.'), three items assessing their depth of engagement/level of knowledge (e.g. 'I know a lot about this field'), and three items regarding their feelings toward the subject (e.g. 'I am interested in this field in general.').

\section{Plan further study}

Students were asked 'What are your post-university career or study plans?' Their responses were coded for whether they said they would pursue further (graduate) study in the field as 'yes', 'maybe', 'undecided', or 'no'.

\section{Desire to pursue interest during career ('IntCar')}

Students rated three items $(\alpha=0.917)$ on a 5-point Likert scale $(1=$ strongly disagree to $5=$ strongly agree $)$ describing whether they wanted to pursue their interest in their field of study during their careers (e.g. 'In my career, I want to be able to pursue my interest in this field.').

\section{Career decidedness ('decided')}

Students completed three items $(\alpha=0.929)$ on a 5 point Likert scale $(1=$ strongly disagree to $5=$ strongly agree), rating how sure they were about their future career plans (e.g. 'I know what I would like to do for a career.').

\section{Career plan facilitators}

Students answered a further open-ended question: 'If you are decided about your post-university plans, what has helped you in clarifying those plans?' Answers were categorised through a process of inductive thematic analysis, with codes closely related to students' words (Braun \& Clarke, 2006). Answers were typically very short $(M=7$ words; ranging from 0 to 24 ) and easily fit a single code.

\section{Demographic variables}

Students reported their programme, year of study, gender, age, race, whether they were first generation in their family to attend university (FirstGen), and their anticipated mark 
according to the UK degree classifications $1^{\text {st }}, 2.1,2.2$, and 3 where $1^{\text {st }}$ is the highest mark. Race was coded as Black, Asian, Minority Ethnic (BAME) or not.

\section{Interview procedure}

The interviewer, who did not know the participants, interviewed each student individually. She began by asking each interviewee to take about five minutes to reflect on the development of their interest in their subject and to depict it in a drawing, using the metaphor of interest as a river. The interviewer suggested that participants start their river with the first time they became interested in the subject and end it with where they imagine they will be in 3 years. They were invited to use the course of the river to illustrate key events and experiences in their lives, such as bends in the river's course to represent turning points in life; changes in the width or narrowness of the river to illustrate changes in the breadth or concentration at different times; tributaries to illustrate new influences flowing in; and rapids or obstructions to depict difficulties. Students then explained their drawing, with the interviewer following up with specific questions to probe how the student initially became interested in the subject, how that influenced their choice of degree course, the influences on their interest during $\mathrm{HE}$, and how those interests were related to their career plans. Interviews took place in a small seminar room in the first author's department, lasted approximately $45 \mathrm{~min}$, and were audiotaped.

Following McAlpine (2016), a narrative approach was used to analyse the interviews. Each interview was transcribed verbatim, and summaries were made of key points. Narratives were then compared to patterns in the quantitative analysis, focusing on the relations between academic subject interest, career interest, and career decidedness. Case examples that best represented the significant patterns found across the survey dataset were selected. Students' scores on significant variables are reported for each interviewee.

\section{Results}

To answer research question 1 (RQ1), we first report survey responses by presenting descriptive statistics, correlational analysis, and then hierarchical regression results. We then report open-ended survey responses on career plan facilitators to address research question 2 (RQ2). Then, we use case examples from the interviews to illustrate significant relationships between interest, desire to pursue that interest in their careers, and career decidedness (RQ1), as well as key factors students thought affected their career decidedness (RQ2).

\section{Interest and career decidedness}

The most common reason students chose their programme ('subject choice') was interest in it $(70 \%)$, followed by career utility (37\%), or self-perceived competence in it $(9 \%)$. Students had relatively well-developed interest in their subjects $(M=3.68, S D=0.51)$. ANOVAs and $t$-tests showed no significant differences on interest across year of study, by discipline, gender, age or first generation status. White students $(M=3.72, S D=0.50)$ had slightly higher interest in the subject than BAME students $(M=3.58, S D=0.50, t=2.456$ (364), $p<0.05, d=0.275$ ). Forty-four percent wanted to pursue further (graduate) study ('PlanFurtherStudy'). Most (79\%) agreed or strongly agreed (indicated by a mean score of 
3.66 or higher on IntCar) that they wanted to pursue their interest in the field during their future career $(M=3.99$; $\mathrm{SD}=0.79)$. There were no significant differences on 'IntCar' by year of study, discipline, age, race, or first generation status. Female students $(M=4.06$, $S D=0.75)$ had slightly higher scores on 'IntCar' than male students $(M=3.88, S D=0.83$, $t=2.243(437), p<0.05, d=0.22$ ).

Fewer than half were decided in their careers; only $46 \%$ had a mean of 3.66 (agree/ strongly agree) or higher on 'decided' $(M=3.24 ; S D=1.05)$. There were no significant differences on career decidedness by year of study, discipline, or any of the demographic variables.

\section{Correlations among study variables}

As shown in Table 1, interest was positively correlated with anticipated mark, desire to pursue further study in the field ('PlanFurtherStudy'), desire to pursue their interests via their career ('IntCar'), and career decidedness ('decided').

\section{Predictors of career decidedness}

Hierarchical regression analysis was used to investigate whether subject interest predicted career decidedness when controlling for the main demographic variables (gender, age, race, first generation), environment variables (programme, year of study), and other variables associated with interest, including anticipated mark, and their plans for further study. Subject interest significantly predicted decidedness, $(\beta=0.219, p=<0.001)$ (Table 2), supporting Hypothesis 1. Following Baron and Kenny's (1986) causal steps approach to assess mediation, we also assessed whether students' desire to pursue their interest in their career ('IntCar') mediated between subject interest and career decidedness ('Decided').

As shown in model 2, subject interest also significantly predicted whether students wanted to continue to pursue their interest during their career ('IntCar') $(\beta=0.506$, $p=<0.001$ ), supporting Hypothesis 2. Finally, in the full model (3), 'IntCar' was the strongest predictor of decidedness $(\beta=0.223, p<0.001)$, and subject interest was no longer significant. The indirect effect of 'IntCar' was significant $(\beta=0.124, p=<0.01)$, consistent with Hypothesis 3. Thus, students' desire to pursue their interest in their career mediated between their interest in their subject and their career decidedness.

\section{Self-reported factors affecting career decidedness}

To answer the second research question, we examined students' responses to the openended question on what had facilitated their career decidedness. Students who were decided about their careers reported that the curriculum, doing their own research into career options, work experience, and their own interests were most helpful to them in their decision-making (Table 3).

\section{Case examples from interviews}

To strengthen inferences about directionality in the mediational analyses above, we draw on qualitative evidence as recommended by MacKinnon et al. (2007). The case examples also put a human face on the data by illustrating each of the key variables that influence 


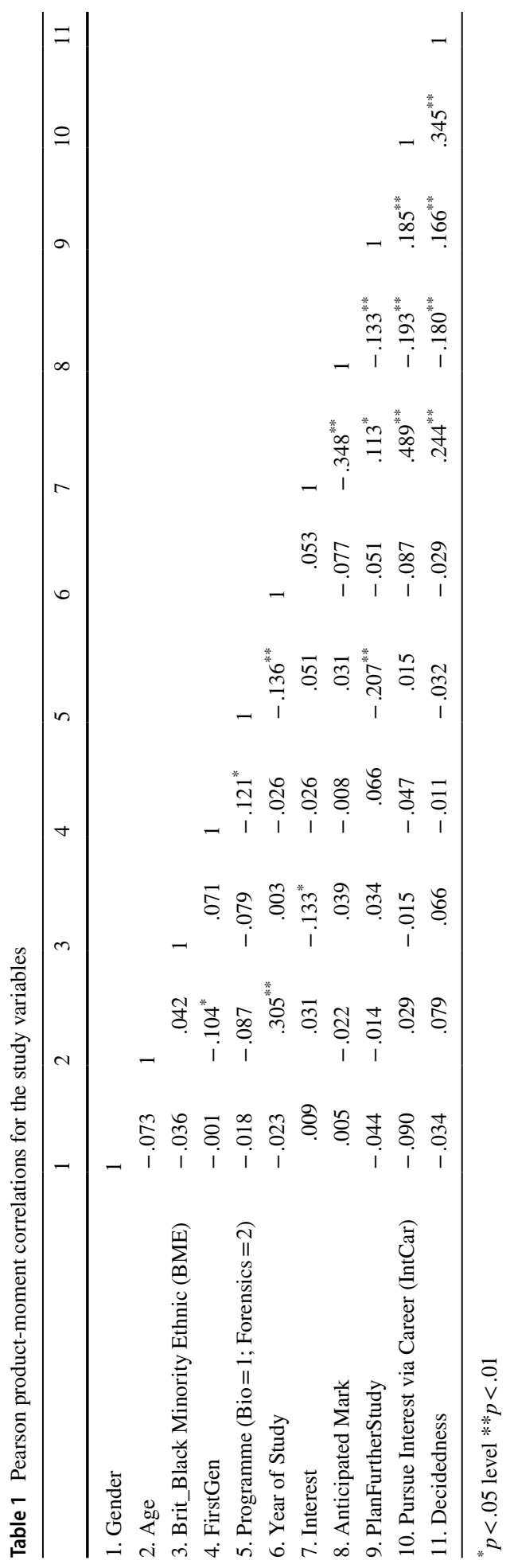


Table 2 Effects of subject interest on career decidedness: mediation by desire to pursue interest through career

\begin{tabular}{|c|c|c|c|c|c|c|}
\hline & \multicolumn{2}{|c|}{$\begin{array}{l}\text { Model } 1 \text { (DV= career } \\
\text { decidedness) }\end{array}$} & \multicolumn{2}{|c|}{$\begin{array}{l}\text { Model } 2(\mathrm{DV}=\text { desire } \\
\text { to pursue interest via } \\
\text { Career:IntCar) }\end{array}$} & \multicolumn{2}{|c|}{$\begin{array}{l}\text { Model } 3 \text { (DV= career } \\
\text { decidedness) }\end{array}$} \\
\hline & $\beta$ & SE & $\beta$ & SE & $\beta$ & SE \\
\hline \multicolumn{7}{|l|}{ Predictors } \\
\hline Gender & -.026 & .115 & -.114 & .074 & -.001 & .114 \\
\hline Age & $.121 *$ & .031 & .077 & .017 & .099 & .031 \\
\hline Brit_BME & .087 & .126 & .029 & .080 & .082 & .124 \\
\hline FirstGen & -.006 & .116 & -.032 & .075 & .006 & .114 \\
\hline Programme & .052 & .136 & .009 & .063 & .044 & .134 \\
\hline Year of Study & -.062 & .071 & $-.112 *$ & .046 & -.037 & .070 \\
\hline Anticipated Mark & -.105 & .099 & .021 & .064 & $-.113 *$ & .098 \\
\hline Interest & $.219 * * *$ & .119 & $.506 * * *$ & .077 & .104 & .135 \\
\hline PlanFurtherStudy & $.132 *$ & .049 & .113 & .031 & .104 & .048 \\
\hline IntCar & & & & & $.223 * * *$ & .085 \\
\hline R Squared & \multirow{2}{*}{\multicolumn{2}{|c|}{$.122 * * *$}} & \multirow{2}{*}{\multicolumn{2}{|c|}{$.30 * * *$}} & $.156 * * *$ & \\
\hline F Change $(1,293)$ & & & & & $11.764 * * *$ & \\
\hline
\end{tabular}

Standardised betas

${ }^{*} p<.05 ; * * \mathrm{p}<.01 * * * p<.001$

career decidedness (RQ1) and the student-identified factors (Table 3) that affect career decidedness (R2). Sam shows the primary pattern of subject interest prompting exploration of career applications. Donna illustrates an alternative pattern when there can be separate evolution of career and subject interests. Lisa shows vividly how anticipated marks can led to indecision. Finally, Jeannette illustrates how practical constraints can force choices between academic subject interest and career focus.

\section{Sam: subject interest prompted exploration into applications}

Most interviewees, like Lucy in the introduction, described how their own interest in their academic subject emerged before their career plans had taken shape, referencing experiences either with their family or in school as triggers for their interest in science. Their academic interest prompted further exploration that led them to gain additional knowledge and experience that supported their career decidedness.

For example, Sam [interest $=3.818$; IntCar $=4.33$; decided $=3.66]$ said he chose bioscience because it was 'fun' and meaningful insofar as he would be positioned to address large global problems such as climate change. Through a family connection, he spent the summer after his first year of university working for an NGO advancing aquaculture techniques in Southeast Asia and expected to spend his second summer in a university genetics lab. He expounded on how genetics can be applied to aquaculture to create a more sustainable food supply. Building on this knowledge, he was clear that he wanted to pursue a $\mathrm{PhD}$ and then work in an applied setting on addressing these larger social issues. He explained how his work experiences enabled him to refine his interests towards a career plan. 'All of 
Table 3 Self-reported factors that helped students become decided in their career plans

\begin{tabular}{|c|c|c|c|}
\hline Factors & $\begin{array}{l}\text { Examples of responses to question: } \\
\text { 'If you are decided about your post-university plans, } \\
\text { what has helped you most in deciding on them?' }\end{array}$ & Frequency & Valid percent \\
\hline (Undecided) & $\begin{array}{l}\mathrm{n} / \mathrm{a} \\
\text { I haven't decided yet }\end{array}$ & 238 & 55.6 \\
\hline Curriculum & $\begin{array}{l}\text { Doing the course and learning the many subjects } \\
\text { Working in labs and specific module content }\end{array}$ & 39 & 9.1 \\
\hline Own career research & $\begin{array}{l}\text { Internet research } \\
\text { Reading up about other options }\end{array}$ & 38 & 8.9 \\
\hline Work experience & $\begin{array}{l}\text { Working in a hospital job } \\
\text { My work experience }\end{array}$ & 25 & 5.8 \\
\hline Interests & $\begin{array}{l}\text { Knowing I definitely enjoy this field... } \\
\text { My interest in the subject }\end{array}$ & 22 & 5.1 \\
\hline Feasibility & $\begin{array}{l}\text { What I'm better at and what I'm not } \\
\text { Employability }\end{array}$ & 14 & 3.3 \\
\hline Family & $\begin{array}{l}\text { Family of bioscientists } \\
\text { My family }\end{array}$ & 12 & 2.8 \\
\hline Career talks or fairs & $\begin{array}{l}\text { The career fairs } \\
\text { Guest lecturers }\end{array}$ & 10 & 2.3 \\
\hline Networking & $\begin{array}{l}\text { Talking to lecturers and to } 2^{\text {nd }} \text { and } 3^{\text {rd }} \text { year students } \\
\text { Talking to professionals in my field }\end{array}$ & 9 & 2.1 \\
\hline Co-curricula & $\begin{array}{l}\text { Extra-curricular activities } \\
\text { The forensic science society }\end{array}$ & 5 & 1.2 \\
\hline Other & $\begin{array}{l}\text { My personal experience of crime scene investigation } \\
\text { (robbery) } \\
\text { The prospect of progress }\end{array}$ & 16 & 3.7 \\
\hline Total & & 428 & 100 \\
\hline
\end{tabular}

these things, even the summer placements are really, really trying just to find something that you got such interest in that you want to keep doing that... in the scientific career'. Thus, the work experiences were stimulated by interest (and good connections) but then were used to further refine his interest.

In most cases, students cited the curriculum as instrumental in honing their interest. Sam was unusual in that he criticised the biosciences degree, 'Because we're always just learning about how this happens...but we're not applying what we've learned...It's never application'. He explicitly compared it to forensics where 'you know that you can apply the knowledge, whereas we're taught very broad things, and you're just given a lot of information, but you don't apply any of the information. So I think it's harder to retain as well'. For Sam, it seemed to be less the curriculum and more his work experience that shaped his career interest.

\section{Donna: separate evolution of career and subject interests}

Most interviewees were similar to the $79 \%$ of surveyed students who agreed that they wanted to continue to pursue their interest in the subject through their careers ('IntCar'), discussing jobs in fertility treatment, genetic counselling, cosmetics, pharmaceuticals, and cancer research. Donna was the only clear exception to this pattern among the 
interviewees. She said, 'I decided to be a [primary school] teacher before I decided to do biology'. She chose 'triple science' at GSCE level (years 10-11; ages 14-16), in which she studied biology, chemistry, and physics, thinking she wanted to become a veterinarian. In year 10, though, she had the opportunity to spend a week shadowing a veterinarian and also spending a week in a primary school. 'And I found the vets didn't really interest me, but in the school I was more engaged and kind of just got on with it, and then got ... a lot of responsibility, and I really enjoyed that week, and I could see myself going into that... And then I got a job in my school's Kids Club and I really enjoyed it, was really passionate about it, and it's kind of proved that working with kids was more important than going into the medicine and vets' side'. She went on, 'I volunteered at the after-school club for 2 years and then I had 2 other work experiences through the school, and I enjoyed all of them and they all kind of reassured that I do want to go into working with kids. Even if it means not going into biology'.

Donna's story demonstrates how a career interest can evolve separately from a subject interest, with above average interest in the subject and full decidedness, although not mediated by an interest in pursuing the subject through their career [interest $=4$; IntCar $=2$; decided $=5$ ]. She continued to plan for a career in primary school teaching, setting up further work experience with children in schools and afterschool clubs and researching different teacher education programmes. Although Donna is unusual in that her career decidedness was not mediated by interest in the choice of her major field in HE and not shaped by the curriculum, her trajectory highlights the role of the other key factors in decidedness: doing her own research into career options, gaining work experience, and exploring and testing one's own interests against those experiences.

\section{Lisa: the role of anticipated marks in indecision}

The marks students anticipated getting were also a significant factor in their career decidedness, with those anticipating a better mark being more decided. Although on the survey, few students (only 9\%) referenced their competency in the subject as the reason for choosing their undergraduate programme, many interviewees did refer to their perceived competencies as part of their stories. Lisa had considered pursuing forensic science because her interest was initially sparked by crime scene investigations, 'I think I had always been interested in DNA aspects of crime and things like that, and watching documentaries and being like, "oh, I didn't know they did this to find out this", but she chose biosciences because she had no interest in policing.

Her story centred around her disappointing performance and low confidence. She was surprised that she got into a 'good' university, against expectation. But she struggled in her first year. She was living off campus with students in other fields and did not have a strong social network in her own field. She described a downward spiral of failing to understand something in lectures, having no one to work it through with, feeling bad about it, then isolating herself further by skipping lectures. She failed her first year and needed to start again. Her second try was much better, largely because she found a group of friends who both helped her with the material and encouraged her to believe in herself and to keep going. She talked about having had many different enthusiasms, 'everything I was interested in I was like "oh, I will do that!" but then you get your grade back and it's not that great and you think "do I really want to do that?"' She toyed with 'neurophysiology, then cancer genetic counselling...bioinformatics, pharmacist, 
social worker at one point. I've just had so many ideas, thinking my degree could go into that, but then I look at my grades, and it's just this self doubt that I'm not good enough to achieve these things'.

She referred to her marks repeatedly, usually in close connection with confusion about her future. 'I don't feel like I'm moving anywhere but I don't have anywhere to move to. Like career wise, what do I want to do, what are my options or do I want to stay where I am... and like, my grades as well, they're not like the best grades, but that also plays a part in decisions. I'm just confused and doing what I have to do to get through the degree but I don't know, future-wise, where I am going'.

She contrasted herself with other students who manage to leave university and get job offers, saying, 'I'm just stuck...' During the interview, she was encouraged to set aside her doubts and anxiety temporarily so she could identify what she really liked best. She quickly focused on educating people about diseases and how they can avoid them, returning to genetic counselling. She recognised the importance of the 'people connection' to her interest, giving examples of labs that had such a connection and those that did not. When asked whether she had explored genetic counselling or other related careers, she said her doubts had always gotten in the way, though she seemed to know what steps she needed to take, such as shadowing at a hospital. Lisa's survey scores [interest $=3$; IntCar $=3$; decided $=3.33$ ] placed her below average on both interest and decidedness. Her performance and confidence (poor anticipated mark) seemed to negatively influence both the process of interest development and career planning.

\section{Jeannette: practical constraints forcing choices between subject and career focus}

Lisa's experience highlights that the degree itself takes a lot of time and attention to be successful and that academic success and the self-perception of academic success is a vital step in forging a career path. Sam was lucky that his family connected him to relevant work experience during his first summer. Donna built on connections she made during her previous schooling to gain relevant work experience. However, many students do not have those connections and must spend a lot of time and energy searching for and applying for relevant summer work experiences or a placement year.

Jeannette, like Lisa, expressed a lot of anxiety and self-doubt and struggled with her academic work, particularly in the first year. She had set a high standard for herself and quickly discovered she needed different study strategies in HE, which she developed and then earned a first class mark on her end-of-first-year exams, which she thought would pave the way to easily finding a third year placement. Instead, 'I was applying for placement. And that took up a lot of time. Because, they say, uh, as soon as you get into second year you should be applying for placement...' She was spending so much time that she 'slacked' on her academic studies, only to discover, 'the thing with second year...is once you slack on something it is really hard to get back'.

In these cases, studying for the degree and doing the work necessary to prepare for careers created a practical, workload problem. 'After wasting loads of time trying to find placements', she shifted her priorities to catching up with her academic work. She experienced the demands of both building her career experience and getting good grades as conflicting in her day-to-day life. Like Lisa, she adopted a strategy of 'doing what I have to do to get through the degree' when her career plans were thwarted with a series of unsuccessful placement applications. 


\section{Discussion}

Study findings suggest that subject interest develops first and provides support for career decidedness (Hypothesis 1). Regression analysis demonstrated that students who were more interested in their subject also wanted to pursue that interest during their careers (Hypothesis 2) and that this desire mediated between subject interest and career decidedness (Hypothesis 3).

Longitudinal studies are needed to establish causality, but students' self-reports showed that their subject interest tended to emerge before clear career goals and was then supported by the curriculum, their own research into career options, and work experiences to support career decidedness. Most students chose their programme based on interest $(70 \%)$, rather than specific career goals, and they wanted to continue to pursue their interest in the subject during their career. The findings are consistent with other research showing interest is the main reason for students' programme choice at university level (e.g. Vulperhorst et al. 2020; Mikkonen et al. 2009).

Theoretically, our research extends understanding of the outcomes of interest. Other studies have focused on how interest supports academic achievement (e.g. Jansen et al., 2016) and various educational processes that underpin educational attainment (see Renninger \& Hidi, 2016 for a review). However, the role of academic interest (that is, interest in one's subject) in career planning has not been investigated. Thus, we fill an important gap.

Practically, this study links interest to career decidedness, a key predictor of successful career outcomes for HE students (Shury et al. 2017). Our conceptualisation of interest as malleable and the findings on students' self-reported influences on career decidedness suggest an active role for HE educators in helping students grow and refine their subject interest and link those interests to career plans. Recent literature on career values has highlighted that students want interesting and meaningful careers (Gallup, 2017, 2019; AGCAS, 2017; Shury et al. 2017). Growing awareness of the importance of students' subjective assessment of their success after graduation, such as interest and meaning, has prompted changes in national graduate outcomes assessments in the UK (https://www. hesa.ac.uk/innovation/outcomes). However, the implications of these revised measures of success for university educators and career services have not been explored. This study fills a gap in understanding students' perspectives on career development and perceived success by examining their interest development during HE. Specifically, we link their interest in their subject, which motivated their choice of subject at university, to their later career decision-making.

Other studies of career decision-making have suggested that students' proactivity lies at the root of finding meaningful, professional level work (Gallup, 2019; Shury et al. 2017; Jackson \& Tomlinson, 2019). Our study traces proactivity back to students' interest in their subject. Surveyed students who were decided in their careers emphasised their own efforts in investigating different career options, as well as their interest and aspects of the curriculum that captured their interest. Thus, interest in the subject seemed to fuel students' desire to continue to pursue that interest during their careers and subsequent proactive exploration, which contributed to their decidedness. Such a pathway is consistent with prior research that shows how interest drives self-regulated behaviour and exploratory engagement (Sansone et al., 2019).

The interviews also showed how interest underpinned the proactive exploration of careers in students like Sam. Yet, interest is not enough on its own. In the regression 
analyses, anticipated mark was also a significant predictor of career decidedness. Thus, students' career planning is also shaped on the basis of their perceived strengths, as illustrated in the case of Lisa.

\section{Implications for practice}

As universities are increasingly being expected to deliver employability, it is important to understand how to support HE students to explore, develop, integrate, and pursue their academic and career interests. Yet responsibility for promotimg students' interest development often falls outside the remit of both careers services and academics. Our study is unique in that it reframes discussions of employability around interest development (Hidi \& Renninger, 2006; Renninger \& Hidi, 2016). Traditionally, vocational interest has been considered a personality trait (e.g. Holland, 1959; Lent et al. 1996; see Su, 2018 for a review). In that paradigm, the job of career advisors is to measure occupational interests, which are presumed to be stable, and match students with jobs that align to their profile.

By contrast, the focus on interest development recognises that interest is malleable and can be supported to develop (Hidi \& Renninger, 2006; Renninger \& Hidi, 2016). Conceptualising interest as developing offers a bridge between student' academic interest and their career interests. Our survey data showed that students' interest in the subject was closely related to their desire to continue to pursue their subject during their career. This linkage was illustrated in the case examples. The finding that most students wanted to pursue their interest during their career is consistent with other recent studies emphasising the importance of intrinsic career values to contemporary students (Jackson \& Tomlinson, 2019; Jackson \& Bridgstock, 2018; Gallup, 2019; AGCAS, 2017; Shury et al. 2017).

Our study contributes further insight by making explicit the link between students' academic interests and their career interests. Doing so offers a framework for articulating the role of academics in students' career development. Traditionally, academics have focused on educating student in the subject, while career services staff have focused on students' career development. Our study showed how both career services staff and academics can support students' overall interest development and, therefore, career decidedness. That is, we showed how students' academic development influences their career development. In the science subjects in this study, students' interest in their subject underpinned and bolstered their career decidedness, which is linked to more positive employment outcomes (Shury et al. 2017). In short, supporting subject interest is not a separate activity from students' career development; instead, it provides a foundation upon which students can build their career plans.

\section{Implications for disciplinary curricula}

Most career education is offered outside regular curricula (Farenga \& Quinlan, 2016). Yet, there have been various attempts to situate career education in disciplinary programmes. Consistent with the dominant approach to employability (Holmes, 2013; Yorke, 2006), most of these efforts have focused on cultivating students' skills rather than interest, though. First, the 'graduate skills' approach to employability has prompted the articulation of and attempts to embed generic graduate attributes and transferable skills across disciplinary curricula (Clarke, 2018; Cranmer, 2006). However, this approach has been difficult to implement successfully (Barrie et al. 2009; Green et al., 2009) and has not been shown to correlate with graduate employment outcomes (Mason et al., 2009). In part, this difficulty 
may be because disciplines have their own particular values, which underpin curricula, teaching, and academics' motivation for teaching (Quinlan, 2016). Generic attributes and skills are typically not expressed in ways that will appeal to academics or students who are steeped in the values inherent in a given discipline. Second, departments also often provide specialised 'employability' courses that students take as part of their disciplinary degree programmes (Foskett \& Johnston, 2006).

In looking more closely at how careers education is offered through programmes, the line between careers education and disciplinary learning blurs (Horn, 2009). Our findings suggest the importance of deliberately exploring and rethinking this blurry intersection, particularly by extending beyond skills to other aspects of students' development. In a qualitative study of embedded careers education in HE, Horn (2009) identified a range of different understandings of careers, of the way students might learn about careers, and what they might learn about careers through their regular courses. Her report sought to 'give us new insights or ways of conceptualising careers education' (Horn, 2009, 9). In fact, she uncovered courses that were not explicitly about career planning, 'but rather focused on developing the students' interests in and analysis of ethical, social or political issues in work and society'. She particularly highlighted how the tools or content of the discipline itself might be linked with careers thinking.

Our participants relied heavily on the curriculum in informing their career decidedness. Thus, it may be helpful if the formal curriculum illustrated career applications of the concepts or disciplinary techniques being taught. Embedding short work placements and job shadowing into programmes may also help students explore and test out their interests (Mason et al., 2009). The Gallup (2019) study found that graduates who had had opportunities to explore the meaning of work during university, to reflect on their interests, and to do internships were more likely to report being in meaningful work after graduation.

Our study makes a significant contribution by shifting the focus from skills development to interest development. While much employability rhetoric has focused on skills, our study suggests that greater attention needs to be paid to developing students' interests and helping them to identify, reflect on, and proactively pursue those interests in their careers (Akkermans et al., 2013).

\section{Implications for career services}

A recent Higher Education Funding Council of England Learning Gain project focused on tracking HE students' work readiness has enabled a tailoring of services, support, and communication to students according to their level of career decidedness (Cobb, 2019; Daubney 2019). Over three years, fifteen UK universities adopted a careers registration process, in which students were surveyed annually about the stage of career planning they were in. This careers registration process is being put in place in many other UK universities and being explored in Australia and New Zealand. This focus on tailoring messages to students' current state of development is central to the educational process, though this particular approach is new to career services.

Extending this principle of 'meeting students where they are' suggests that career advisers need to meet students at their interest in the subject, not just their level of career decidedness. While it is common for career counsellors to emphasise the flexibility of undergraduate degrees in preparing students for a variety of careers, students are invested in and committed to their interest in their subject. Thus, it may be useful to start with helping students clarify their interest in the subject and highlighting career 
options that are closely related to particular aspects of the curriculum. New ways of collaborating with academics may also be appropriate to ensure that not only does the curriculum support students' interest, but also supports their reflection on their values and interests (Akkermans et al., 2013).

\section{Limitations and implications for research}

Longitudinal research is needed to further establish causal connections between students' interest and career decidedness, particularly research that tracks students from secondary school through HE. Students' proactive exploration also seems to be a key mediating variable that was not studied quantitatively here and should be included in future models, consistent with Sansone, Geering, Thoman, and Smith's model (Sansone et al. 2019) and research on career proactivity (e.g. Jackson \& Tomlinson, 2019). Two of the student narratives (Sam and Lisa) also suggested how students blend and combine their interests to create particular 'lines of practice' (Azevedo, 2011). Further research into the process of students' interest development, including students' reflection on, refinement of, and blending of interests, would better illuminate students' employability journeys. Such research could inform the design and evaluation of interventions to help students balance academic work and preparation for meaningful and rewarding careers. This study focused only on undergraduate science students. Understanding how to support science students is particularly important given policy emphasis on STEM careers and the higher costs of lab-based sciences. However, the observed pattern in which subject interest emerged first and then supported career decidedness may not hold when looking at degree programmes more closely tied to particular careers (e.g. nursing or medicine). Likewise, it is possible that in fields less closely associated with particular careers than biosciences and forensics (e.g. humanities subjects), a pattern of separate evolution of subject and career interests (as seen in Donna's case) may be more common. Similar studies in a wider range of fields are needed. Further study in other countries would extend the generalisability of the findings.

\section{Conclusion}

We conclude that universities striving to enhance graduates' employability need to focus not just on employability skills, but on supporting the development of students' interests. Conceptualising interest as a variable that develops, we found that students who were more interested in their subject also tended to want to pursue that disciplinary interest in their careers and tended to be more decided in their career plans. Decidedness is a key factor identified in successful employment outcomes. Open-ended comments and interviews suggested that interest drove students to proactively research and explore career options that would allow them to continue to pursue those interests.

Students pointed to the curriculum as a key element in their career decidedness. Thus, academics and career services staff may need to reconceptualise careers education, focusing more on using disciplinary curricula as the impetus for students' career planning. 
Funding Funded by a Teaching Enhancement Small Support Award, University of Kent. The authors thank Ashleigh Francis and Sophie Wiegmann for assistance with data entry, the student participants for sharing their experiences and perspectives, and the academics who promoted the project to their students.

Open Access This article is licensed under a Creative Commons Attribution 4.0 International License, which permits use, sharing, adaptation, distribution and reproduction in any medium or format, as long as you give appropriate credit to the original author(s) and the source, provide a link to the Creative Commons licence, and indicate if changes were made. The images or other third party material in this article are included in the article's Creative Commons licence, unless indicated otherwise in a credit line to the material. If material is not included in the article's Creative Commons licence and your intended use is not permitted by statutory regulation or exceeds the permitted use, you will need to obtain permission directly from the copyright holder. To view a copy of this licence, visit http://creativecommons.org/licenses/by/4.0/.

\section{References}

AGCAS (2017). First-year career readiness survey report. Sheffield, UK: Association of Graduate Careers Advisory Services. https://www.agcas.org.uk/Knowledge-Centre/b671b272-c0fe-40b4-85dd-1c19b 529ddd6. Accessed 1 Feb 2021.

Akkermans, J., Brenninkmeijer, V., Huibers, M., \& Blonk, R. W. B. (2013). Validation of the career competencies questionnaire. Journal of Career Development, 40(3), 245-267. https://doi.org/10.1177/08948 45312467501

Azevedo, F. S. (2011). Lines of practice: A practice-centered theory of interest relationships. Cognition and Instruction, 29(2), 147-184. https://doi.org/10.1080/07370008.2011.556834

Azevedo, F. S. (2015). Sustaining interest-based participation in science. In K. A. Renninger, M. Nieswandt, \& S. Hidi (Eds.), Interest in mathematics and science learning (pp. 281-296). AERA.

Baron, R. M., \& Kenny, D. A. (1986). The moderator-mediator variable distinction in social psychological research: Conceptual, strategic, and statistical considerations. Journal of Personality and Social Psychology, 51(6), 1173-1182. https://doi.org/10.1037//0022-3514.51.6.1173

Barrie, S., Hughes, C., \& Smith, C. (2009). The national graduate attributes project: Integration and assessment of graduate attributes in curriculum. Sydney: Australian Learning and Teaching Council. http:// hdl.voced.edu.au/10707/327383. Accessed 01 Feb 2021.

British Broadcasting Corporation. (2021). "GCSE Options: Everything you need to know about choosing your GCSE subjects”. Retrieved 15 July 2020 from https://www.bbc.co.uk/bitesize/articles/zrjh92p

Braun, V., \& Clarke, V. (2006). Using thematic analysis in psychology. Qualitative Research in Psychology, 3(2), 77-101. https://doi.org/10.1191/1478088706qp063oa

Clarke, M. (2018). Rethinking graduate employability: The role of capital, individual attributes and context. Studies in Higher Education, 43(11), 1923-1937. https://doi.org/10.1080/03075079.2017.1294152

Cobb, F., \& Winter, D. (2018). Careers registration learning gain project: Interim findings. University of London Careers Group.

Cobb, F. (2019). 'There's no going back': The transformation of HE careers services using big data. Journal of the National Institute for Career Education and Counselling, 42(1), 18-25.

Daubney, K. (2019). What difference does it make? Using careers registration to define and measure student careers learning gain at King's College London. Paper presented at the annual meeting of the Society for Research into Higher Education, Newport, Wales, UK, December 11-13.

Cranmer, S. (2006). Enhancing graduate employability: Best intentions and mixed outcomes. Studies in Higher Education, 31(2), 169-184. https://doi.org/10.1080/03075070600572041

Dewey, J. (1913). Interest and Effort in Education. Houghton Mifflin.

Eccles, J. S., \& Wigfield, A. (2020). Expectancy-value theory: Current status, current controversies, and a look ahead. Contemporary Educational Psychology, 61https://doi.org/10.1016/j.cedpsych.2020. 101859

Farenga, S. A., \& Quinlan, K. M. (2016). Classifying university employability strategies: Three case studies and implications for practice and research. Journal of Education and Work, 29(7), 767-787. https:// doi.org/10.1080/13639080.2015.1064517

Foskett, R. \& Johnston, B. (2006) Curriculum development and career decision-making in higher education: credit-bearing careers education. Manchester, UK. Higher Education Careers Services Unit. https://eprints.soton.ac.uk/41973/. Accessed 13 Apr 2020. 
Green, W., Hammer, S., \& Star, C. (2009). Facing up to the challenge: Why is it so hard to develop graduate attributes? Higher Education Research and Development, 28(1), 17-29. https://doi.org/10.1080/07294 360802444339

Harter, J. K., Schmidt, F. L., Agrawal, S. Plowman, S. K \& Blue, A. (2016). The relationship between engagement at work and organizational outcomes. $2016 Q^{12}$ Meta-analysis: Ninth edition. Washington, D.C.: Gallup. https://news.gallup.com/reports/191489/q12-meta-analysis-report-2016.aspx. Accessed 13 Apr 2020.

Gallup. (2019). Forging pathways to meaningful work: The role of higher education. Washington, D.C.: Gallup. https://www.gallup.com/education/248222/gallup-bates-purposeful-work-2019.aspx. Accessed 13 Apr 2020

Gallup. (2017). How millennials want to work and live. Washington, D.C.: Gallup. https://www.gallup.com/ workplace/238073/millennials-work-live.aspx. Accessed 1 Feb 2021.

Gottlieb, J., Oudeyer, P.-Y., Lopes, M., \& Baranes, A. (2013). Information seeking, curiosity, and attention: Computational and neural mechanisms. Trends in Cognitive Sciences, 17(11), 585-593. https://doi.org/ 10.1016/j.tics.2013.09.001

Harackiewicz, J. M., Durik, A. M., Barron, K. E., Linnenbrink, L., \& Tauer, J. M. (2008). The role of achievement goals in the development of interest: Reciprocal relations between achievement goals, interest, and performance. Journal of Educational Psychology, 100(1), 105-122. https://doi.org/10. 1037/0022-0663.100.1.105

Hecht, C. A., Grande, M. R., \& Harackiewicz, J. M. (2021). The role of utility value in promoting interest development. Motivation Science, 7(1), 1-20. https://doi.org/10.1037/mot0000182

Hidi, S., \& Renninger, K. A. (2006). The four-phase model of interest development. Educational Psychologist, 41(2), 111-127. https://doi.org/10.1207/s15326985ep4102_4

Holland, J. L. (1959). A theory of vocational choice. Journal of Counseling Psychology, 6(1), 35-45. https://doi.org/10.1037/h0040767

Holmes, L. (2013). Competing perspectives on graduate employability: Possession, position or process? Studies in Higher Education, 38(4), 538-554. https://doi.org/10.1080/03075079.2011.587140

Horn, J. (2009). Values at work: A qualitative study of careers education in higher education. Reading, UK: Centre for Career Management Skills.

Jackson, D., \& Bridgstock, R. (2018). Evidencing student success in the contemporary world-of-work: Renewing our thinking. Higher Education Research \& Development, 37(5), 984-998. https://doi.org/ $10.1080 / 07294360.2018 .1469603$

Jackson, D., \& Tomlinson, M. (2019). Career values and proactive career behaviour among contemporary higher education students. Journal of Education and Work, 32(5), 449-464. https://doi.org/10.1080/ 13639080.2019.1679730

Jansen, M., Lüdtke, O., \& Schroeders, U. (2016). Evidence for a positive relation between interest and achievement: Examining between-person and within-person variation in five domains. Contemporary Educational Psychology, 46, 116-127. https://doi.org/10.1016/j.cedpsych.2016.05.004

Lent, R. W., Brown, S., \& Hackett, G. (1996). Career development from a social cognitive perspective. In D. Brown, L. Brooks, and Associates (Eds.), Career Choice and Development (3rd Ed.) (pp. 373- 421). San Francisco, CA: Jossey-Bass.

MacKinnon, D. P., Fairchild, A. J., \& Fritz, M. S. (2007). Mediation analysis. Annual Review of Psychology, 28, 593-614. https://doi.org/10.1146/annuarev.psych.58.110405.085542

Mason, G., Williams, G., \& Cranmer, S. (2009). Employability skills initiatives in higher education: What effects do they have on graduate labour Market Outcomes? Education Economics, 17(1), 1-30. https:// doi.org/10.1080/09645290802028315

McAlpine, L. (2016). Why might you use narrative methodology? A story about narrative. Eesti Haridusteaduste Ajakiri, 4(1), 32-57. https://doi.org/10.12697/eha.2016.4.1.02b

Mikkonen, J., Heikkilä, A., Ruohoniemi, M., \& Lindblom-Ylänne, S. (2009). 'I study because I'm interested': University students' explanations for their disciplinary choices. Scandinavian Journal of Educational Research, 53, 229-244. https://doi.org/10.1080/00313830902917261

Nuutila, K., Tapola, A., Tuominen, H., Kupiainen, S., Páásztor, A., and Niemivirta, M. (2020). Reciprocal predictions between interest, self-efficacy, and performance during a task. Frontiers in Education, 16. https://doi.org/10.3389/feduc.2020.00036

Quinlan, K. M. (2016). Developing student character through disciplinary curricula: An analysis of UK QAA subject benchmark statements. Studies in Higher Education, 41(6), 1041-1054. https://doi.org/ 10.1080/03075079.2014.966069

Quinlan, K. M. (2019). What triggers students' interest during higher education lectures? Personal and situational variables associated with situational interest. Studies in Higher Education, 44(10), 1781-1792. https://doi.org/10.1080/03075079.2019.1665325 
Renninger, K. A., \& Hidi, S. (2016). The Power of Interest for Motivation and Engagement. Routledge.

Ryan, R. M., \& Deci, E. L. 2020. Intrinsic and extrinsic motivation from a self-determination theory perspective: Definitions, theory, practices, and future directions. Contemporary Educational Psychology, 61. https://doi.org/10.1016/j.cedpsych.2020.101860

Sansone, C., Geering, D. M., Thoman, D. B., \& Smith, J. L. (2019). Self-regulation of motivation: A renewable resource for learning. In K. A. Renninger \& S. Hidi (Eds.), The Cambridge handbook of motivation and learning (pp. 87-110). Cambridge University Press.

Shury, J., Vivian, D., Turner, C., \& Downing, C. (2017). Planning for success: Graduates' career planning and its effect on graduate outcomes. London, UK: Department for Education.

Sortheix, F., Dietrich, J., Chow, A., \& Salmela-Aro, K. (2013). The role of career values for work engagement during the transition to working life. Journal of Vocational Behavior, 83(3), 466-475. https://doi. org/10.1016/j.jvb.2013.07.003

Su, R. (2018). The three faces of interests: An integrative review of interest research in vocational, organizational and educational psychology. Journal of Vocational Behavior 116(Part B), Article 103240. https://doi.org/10.1016/j.jvb.2018.10.016

Tomlinson, M. (2007). Graduate employability and student attitudes and orientations to the labour market. Journal of Education and Work, 20(4), 285-304. https://doi.org/10.1080/13639080701650164

UCAS. (2021a). "Post 16 qualifications: The routes available to you after GCSE's or Nationals". Retrieved 15 July 2021 from https://www.ucas.com/further-education/post-16-qualifications

UCAS. (2021b). "How to choose the right undergraduate course for you". Retrieved 15 July 2021 from https:/www.ucas.com/undergraduate/what-and-where-study/how-choose-right-undergradu ate-course-you

Yorke, M. (2006). Employability in higher education: What it is and what it is not. Learning and employability series one. York: Enhancing Student Employability Co-ordination Team and The Higher Education Academy. https://s3.eu-west-2.amazonaws.com/assets.creode.advancehe-document-manager/ documents/hea/private/id116_employability_in_higher_education_336_1568036711.pdf. Accessed 13 Apr 2020

Vulperhorst, J. P., van de Rijst, R. M., \& Akkerman, S. F. (2020). Dynamics in higher education choice: Weighing one's interests in light of available programmes. Higher Education, 79, 1001-1021. https:// doi.org/10.1007/s10734-019-00452-X

Publisher's note Springer Nature remains neutral with regard to jurisdictional claims in published maps and institutional affiliations. 